Magna Scientia Advanced Research and Reviews

eISSN: 2582-9394

Cross Ref DOI: $10.30574 / \mathrm{msarr}$

Journal homepage: https://magnascientiapub.com/journals/msarr/

(REVIEW ARTICLE)

\title{
Detection techniques aiding in the diagnosis of the novel coronavirus SARS-Cov-2 induced infections
}

\author{
Chateen Izaddin Ali Pambuk* and Fatma Mustafa Muhammad * \\ College of Dentistry; Dept. of Basic science; University of Tikrit; Iraq.
}

Magna Scientia Advanced Research and Reviews, 2021, 02(02), 112-115

Publication history: Received on 12 July 2021; revised on 28 August 2021; accepted on 30 August 2021

Article DOI: https://doi.org/10.30574/msarr.2021.2.2.0063

\begin{abstract}
Some people may not be able to distinguish between the symptoms of the emerging corona virus 2019 and other respiratory diseases, and some individuals may be infected with the virus without symptoms, or without noticeable symptoms, so it is important to conduct a corona examination to diagnose the disease.

To monitor the new Corona virus infections, many tests have been developed since the SARS-Cov 2 virus first appeared at the end of last year until today. About 350 types of detection techniqes are currently used in all laboratories of the world. They can be divided into three pivotal sections: the [PCR] examination, which is also known as the "polymerase chain reaction" examination, then the [antigen-tests] known as antibody tests, and finally the ELISA test. The aim of this descriptive minireview, generally, is to shed light on the main detection techniques used in Covid 19 diagnosis.
\end{abstract}

Keywords: Detection Techniques; Diagnosis; Novel coronavirus; SARS-Cov-2; Infections; PCR and rapid Antigen test

\section{Introduction}

Corona disease is a disease that affects the respiratory system occurs as a result of infection with a specific type of corona virus, which may lead to infection with the Middle East respiratory syndrome-related coronavirus [MERS-CoV]. In fact, the coronavirus family includes seven different types of viruses that can infect humans; Four of them - the most causing common - colds, in addition to the two dangerous types that cause serious infections in the respiratory tract and lungs, known as MERS, and SARS, or what is known as severe acute respiratory syndrome and the Wuhan coronavirus is the new type, which was recently added to the list of corona viruses that can infect humans causing Covid$19[1]$.

A new type of corona virus appeared in China, and it received several names such as: the novel corona virus, the emerging corona virus, covid 19, the new mutated corona virus, or the nCov19 corona virus; Where the initial reports of its spread were recorded in mid-December of 2019, the recorded cases of infection are still rising rapidly and reaching more than 200 million cases and 6 million deaths [1,2].

\section{Corona disease diagnosis}

The diagnosis of corona disease depends on the symptoms appearing on the infected person, even if he has previously traveled to one of the countries where the disease is spread, and among the tests that can be done to diagnose corona disease is the polymerase chain reaction test, Coronavirus rapid antigen test and Blood Test $[1,2]$.

\footnotetext{
* Corresponding author: Chateen Izaddin Ali Pambuk and Fatma Mustafa Muhammad; E-mail: dr.chatin2@yahoo.com College of Dentistry; Department of Basic science; University of Tikrit; Iraq; ORCID ID : https://orcid.org/0000-0002-9893-8085 


\section{Coronavirus polymerase chain reaction (PCR) test}

The polymerase chain reaction test for the Corona virus helps to detect the genetic material of the emerging corona virus, through the technique of polymerase chain reaction, which depends on amplifying small parts of the DNA of the Corona virus, as the virus is copied hundreds of thousands of times, in order to ensure the presence of the virus accurately [3].

One of the most common tests currently used and it is the one approved in the first place by the World Health Organization, as well as China, the cradle of the epidemic. This examination measures the "polymethral chain reaction" in the human body, and has a long history of detecting several viruses, whether they are related to influenza or acquired immunodeficiency [AIDS], or enteroviruses, and viruses associated with the respiratory system, including viruses of the Corona family $[2,3]$.

In this examination, samples are taken from saliva from the throat, or a sample from a lung abscess. The second step is to determine whether the extracted sample contains the genetic code for SARS-Covid-2 [the genome of the virus]. Before that, all the genetic information in the sample is isolated, to obtain pure material that is mixed with the emerging coronavirus itself.

Through a chemical process based on the electrophoresis technique [using agarose gel], it is monitored whether the virus genome is present in the sample taken or not. If detected, this means that the person is infected with the emerging corona virus. But if the genetic code of the virus is not found, this does not mean that the person is not infected, it is very likely that the virus is present in the human body, and it did not reach the sample that was extracted $[4,3,1]$.

The positive result of the polymerase chain reaction analysis of the Coronavirus indicates that the individual has an active infection, and that the individual is contagious, while the negative result indicates that he may not be infected, and you may still be infected later, as there may be an insufficient amount of virus in the sample to detect it [4].

\section{How is a PCR test performed?}

The corona examination is performed through the polymerase chain reaction test through the collection of a nasopharyngeal swab, in which the health care provider inserts a long swab into the nostril and takes a sample from the back of the nose, or an oropharyngeal swab by using a long swab in the back of the throat Or, the health care provider may ask the individual to spit into a tube in order to collect saliva [3].

\section{Coronavirus rapid antigen test}

The Rapid Antigen Test helps to detect the presence of an active infection with the emerging corona virus, by detecting the presence of certain proteins on the surface of the Corona virus called antigens, and what distinguishes this test is that the result of the corona examination is fast, as it takes a period of time Less than an hour to obtain the test results, and it should be noted that the accuracy of the rapid antigen test is not high, and we consider the positive result correct, while there is a greater chance of false negative results with antigen tests, that is, the negative result does not confirm that the individual is not infected with the emerging coronavirus [5,1].

This test was developed last summer, and the developer companies took the initiative to put forward types for home use, similar to the pregnancy test that can be purchased at the pharmacy. However, home examinations did not show the effectiveness promised by the producing companies. These tests require a connected device that is only available in laboratories. There is a fundamental challenge preventing the development of these examinations, and it is reflected in the failure to ensure a comprehensive view of the epidemiological situation, as it occurs outside the control of the health authorities [6].

In practice, a sample of saliva was used for this examination. One of its advantages is that it is the fastest it has ever been because it delivers a result in 15 minutes, but it is also not as accurate as a PCR. However, many doctors are betting on this type of examination because of its speed because it quickly detects those with a large viral load, which contributes to limiting the infection.

In general a rapid antigen test is done by taking a nasopharyngeal swab, nasal swab, or throat swab, and a sample of saliva may be collected. The positive result of the rapid antigen test indicates that the individual is infected and may be 
contagious, and the negative result may indicate that the individual may not be infected with the emerging corona virus, and it should be noted that the accuracy of the rapid tests is less $[7,6,2]$.

\section{Coronavirus blood test}

The antibody blood test is used to detect the antibodies produced by the body's immune system when it responds to an individual's infection with the emerging coronavirus, and the antibody blood test is used to detect an individual's previous infection with the Coronavirus, and it is not preferable to use it to detect an existing infection, as the antibodies do not appear. In the individual's body only after one or two weeks of infection.

There are two types of antibodies that the body produces when infected with the Coronavirus, IgM antibodies, which the body makes for two weeks and then their level decreases, and IgG antibodies, which the body needs a longer period to appear, but it lasts longer [8,7].

This test, also called the enzyme immunoassay, is the most accurate, but the most expensive one. This test detects the presence of antibodies against HIV in the blood serum. It is usually used to detect AIDS. Blood samples are taken, and in a complex scientific method, the amount of antibodies in the blood is calculated and the level of acquired immunity against viral diseases, including the emerging corona virus, is calculated [8].

This particular examination classifies the ability of former patients to donate blood plasma to treat severely injured patients. Copies of this examination were developed for use in the doctors' office, but their use remains limited due to their high cost.

The blood test for antibodies is performed by drawing a blood sample from a vein in the arm of the individual using a small needle, and it is collected in a special test tube for later analysis, or the sample may be collected through a finger prick. The positive result of the antibody test indicates that the individual was previously infected with the virus without specifying the time of infection, and indicates protection from re-infection, while the negative result indicates that the immune system did not produce antibodies, which indicates that the individual was not previously infected $[9,8,7]$.

\section{Conclusion}

The Important techniques of the novel corona virus SARS-CoV-2 can be divided into three pivotal sections: the [PCR] examination, which is also known as the "polymerase chain reaction" examination, then the [antigen-tests] known as antibody tests, and finally the ELISA test.

\section{Compliance with ethical standards}

\section{Acknowledgments}

Many thanks is going to Dr. Fatma Mustafa Muhammad for the spectacular aiding and writing in the course of preparation of the current minireview.

\section{Disclosure of conflict of interest}

There is no conflict of interest.

\section{References}

[1] Corman VM, Landt O, Kaiser M, Molenkamp R, Meijer A, Chu DK, Bleicker T, Brunink S, Schneider J, Schmidt ML, Mulders DG, Haagmans BL, van der Veer B, van den Brink S, Wijsman L, Goderski G, Romette JL, Ellis J, Zambon M, Peiris M, Goossens H, Reusken C, Koopmans MP, Drosten C. Detection of 2019 novel coronavirus [2019-nCoV] by real-time RT-PCR. Euro Surveill. 2020; 25[3]: 2000045.

[2] Rai P, Kumar BK, Deekshit VK, et al. Detection technologies and recent developments in the diagnosis of COVID19 infection. Appl Microbiol Biotechnol. 2021; 105: 441-455.

[3] Alagarasu K, Choudhary ML, Lole KS, Abraham P, Potdar V. Evaluation of RdRp \& ORF-1b-nsp14-based real-time RT-PCR assays for confirmation of SARS-CoV-2 infection: An observational study. Indian J Med Res. 2020; 151[5]: 483-485. 
[4] Chan PK, To WK, Ng KC, Lam RK, Ng TK, Chan RC, Wu A, Yu WC, Lee N, Hui DS, Lai ST, Hon EK, Li CK, Sung JJ, Tam JS. Laboratory diagnosis of SARS. Emerg Infect Dis. 2004; 10 [5]: 825-831.

[5] Konrad R, Eberle U, Dangel A, Treis B, Berger A, Bengs K, Fingerle V, Liebl B, Ackermann N, Sing A. Rapid establishment of laboratory diagnostics for the novel coronavirus SARS-CoV-2 in Bavaria, Germany, February 2020. Euro Surveill. 2020; 25[9].

[6] Loeffelholz MJ, Tang YW. Laboratory diagnosis of emerging human coronavirus infections - the state of the art. Emerg Microbes Infect. 2020; 9[1]: 747-756.

[7] Long QX, Tang XJ, Shi QL, Li Q, Deng HJ, Yuan J, Hu JL, Xu W, Zhang Y, Lv FJ, Su K, Zhang F, Gong J, Wu B, Liu XM, Li JJ, Qiu JF, Chen J, Huang AL. Clinical and immunological assessment of asymptomatic SARS-CoV-2 infections. Nat Med. 2020; 26: 1200-1204.

[8] Bundschuh C, Egger M, Wiesinger K, Gabriel C, Clodi M, Mueller T, Dieplinger B. Evaluation of the EDI enzyme linked immunosorbent assays for the detection of SARS-CoV-2 IgM and IgG antibodies in human plasma. Clin Chim Acta. 2020; 509: 79-82.

[9] Infantino M, Grossi V, Lari B, Bambi R, Perri A, Manneschi M, Terenzi G, Liotti I, Ciotta G, Taddei C, Benucci M, Casprini P, Veneziani F, Fabbri S, Pompetti A, Manfredi M. Diagnostic accuracy of an automated chemiluminescent immunoassay for anti-SARS-CoV-2 IgM and IgG antibodies: an Italian experience. J Med Virol. 2020; 92: 16711675. 